American Association of Hispanics in Higher Education, Inc.

\title{
Latino Access to Community Colleges and Hispanic-Serving Institutions:
} A National Study

\author{
Anne-Marie Núñez \\ University of Texas at San Antonio \\ P. Johnelle Sparks \\ University of Texas at San Antonio \\ Eliza Hernández \\ University of Texas at San Antonio
}

This Scholarly Paper was commissioned for the 5th Annual Conference of the American Association of Hispanics in Higher Education, 2010. 


\begin{abstract}
This article examines the factors that affect Latino students' enrollment in community colleges that are Hispanic-Serving Institutions (HSIs). We analyzed a national sample of first-time, first-year beginning college students to explore the demographic backgrounds, academic characteristics, college choice considerations, and local contexts that are associated with enrolling in community colleges that are HSIs. Community college HSIs appear to enroll students with higher educational expectations but also a higher risk of dropping out of college.
\end{abstract}

KEYWORDS: Hispanic, Latino, community colleges, Hispanic-Serving Institutions, college access, college choice 


\section{INTRODUCTION}

Latinos $^{\mathrm{i}}$ now constitute the largest, youngest, and fastest growing nonWhite population in the U.S. By 2015, half the projected increase in young adults 18 to 24-years-old is expected to be Latino (Martinez, 2002); by 2030, approximately three out of ten people are expected to be of Latino heritage (Pew Foundation, 2008). However, Latino high school graduates' college enrollment rates have remained relatively flat since the late 1970s, and Latinos continue to have the lowest educational attainment rates in the U.S. (St. John, 2003). Increasing Latinos' college graduation rates will be essential to the Obama administration's goal of having the U.S. reach the highest educational attainment rate in the world by 2020 (Kelly, Schneider, \& Carey, 2010).

Latino college students tend to begin their postsecondary educations in community colleges. About 16 percent of all community college students are Latino, while Latinos comprise about half that proportion (9\% and 7\%, respectively) of the total student enrollment in the public 4-year and private 4year sectors (National Center for Education Statistics, 2009). Among 2003-4 high school graduates, $46 \%$ of Hispanic, compared with $28 \%$ of White, $30 \%$ of African American, and $25 \%$ of Asian students enrolled in a community college directly after high school (National Center for Education Statistics, 2008b).

Latinos are also heavily enrolled in Hispanic-Serving Institutions (HSIs). HSIs, which include community colleges and 4-year postsecondary institutions, 
enroll nearly half (46 percent) of the entire Hispanic college student population (Johnson, Conrad, \& Perna, 2006; Mercer \& Stedman, 2008). HSIs are defined by the government as non-profit institutionsthat enroll at least 25 percent Latinos, and HSIs that receive additional government Title $\mathrm{V}$ funding for Minority-Serving Institutions also enroll a significant percentage of low-income students (Johnson et al., 2006). By comparison, Historically Black Colleges and Universities (HBCUs), another main category of Minority-Serving Institutions, enroll just 14 percent of African American undergraduates (Mercer \& Stedman, 2008).

Despite HSIs' receipt of substantial federal funding on the basis of their large Hispanic enrollments, virtually no large scale quantitative studies examine factors that distinguish Hispanic students who enroll in HSIs from those who do not (Contreras et al., 2008; Johnson et al., 2006). Leading higher education researchers have characterized research on HSIs as "virtually ignored" (Pascarella, 2006, p. 514), and as "inadequate" and "catalogue-like" (Baez, Gasman, \& Turner, 2008, p. 9). Understanding characteristics of students in HSIs and other Minority-Serving Institutions has been identified as a key direction for future higher education research (Pascarella, 2006).

Community colleges and HSIs serve as critical gateways to higher education for Latinos; therefore, understanding the influences on students' enrollment in these types of institutions is important. This study's purpose is to examine the factors that are related to Latino students' enrollment in 2-year HSIs. 
We address the following questions: (1) Do the demographic backgrounds, academic characteristics, college choice behaviors, and local environmental contexts of community college students differ among a diverse set of racial/ethnic groups?; (2) Do the demographic backgrounds, academic characteristics, college choice behaviors, and local environmental contexts of community college students who are enrolled in HSIs differ compared with those of community college students who are not enrolled in HSIs?; and (3) Which of these factors are independently associated with enrollment in community colleges that are HSIs?

\section{LITERATURE REVIEW}

The approximately 1,045 community colleges in the U.S. enroll about $35 \%$ of all college students; California's community college system, the largest in the U.S., enrolls almost one-quarter $(23 \%)$ of all community college students in the nation (National Center for Education Statistics, 2008b). Since 2007, community colleges have seen a 17\% enrollment surge (Mullin \& Phillipe, 2009). The economic recession, community colleges' lower tuition and fees, these colleges' community outreach and marketing efforts, limitations on higher education affirmative action policies in some states, and constraints on the capacity to meet the demand for enrollment in public 4-year higher education, have all contributed to this marked increase in community college enrollment (Mullin \& Phillipe, 2009). 
Community colleges are charged with several missions. These include offering: (a) collegiate studies to prepare students to transfer to 4-year institutions; (b) vocational education to prepare students for jobs; (c) developmental education to help students develop basic academic skills; and (d) community and multicultural education to serve members of the local area (Cohen \& Brawer, 2008). According to Cohen and Brawer (2008) and Laden (2001), community colleges appeal to Latino students for several reasons. They are more geographically dispersed than 4-year institutions, and thus are closer to home for many Hispanic students. These institutions' lower tuition and fees are particularly appealing to Hispanics, who tend to be more averse than other groups to taking out loans for postsecondary education (Dowd, 2008). Moreover, community colleges are often perceived to be welcoming environments with smaller classes and flexible admissions (and, where necessary, re-admissions) requirements. They also offer more flexible scheduling and part-time attendance opportunities, which are particularly suitable for students who work. Community colleges also tend to offer academic and student support programs that address the needs of students from underrepresented and non-traditional backgrounds (Laden, 2001).

Accordingly, about half (47\%) of HSIs are community colleges (Mercer \& Stedman, 2008). Like community colleges, HSIs are seeing substantial enrollment increases, and several "emerging HSIs" are likely to reach HSI status in the coming years (Santiago \& Andrade, 2010). Although there are questions as to the 
extent to which HSIs intentionally are promoting the success of Hispanic students (Contreras et al., 2008), there are some indicators that Hispanic students attending HSIs have more positive experiences and outcomes than those attending non-HSI institutions. In California, Hispanic students who attend 2-year HSIs transfer to 4year institutions at higher rates than those not enrolled in HSIs (Laden, 2001; Laden, Hagedorn, \& Perrakis, 2008). Two-year HSIs have a higher proportion of Hispanic faculty, who can offer enhanced understanding of students' cultural backgrounds and serve as mentors (Laden, 2001). Although community colleges and HSIs serve a critical role in Hispanics' college access, little is known about how the characteristics of Hispanics enrolled in Hispanic-Serving community colleges compare to those of their counterparts who are enrolled in community colleges that are not HSIs.

\section{CONCEPTUAL FRAMEWORK}

Economic models of college choice assume that a student rationally chooses a to enroll in a particular college based on assessing how the perceived monetary benefits of attending a certain college outweigh those of either not attending college at all, or of attending a different college (Dowd, 2008; Perna, 2006). In addition, these models of college choice assume that students will seek to attend the most selective colleges that they can, in order to maximize their acquisition of human capital (Becker, 1993). However, Hispanic students do not necessarily evidence such an approach to choosing colleges. Bowen, Chingos, and 
McPherson (2009) found that Hispanics, more than any other racial/ethnic group, have a tendency to select schools for which they are academically overqualified for example, to select a community college over a 4-year institution. Another qualitative study suggested that highly qualified Hispanic students admitted to highly selective colleges may instead choose to attend less selective HSIs that are more inexpensive, closer to home, and perceived as welcoming to students of color (Santiago, 2007). Traditional econometric models of college choice may not account for the full range of factors associated with where Hispanic students attend college (Dowd, 2008; Perna, 2006). Moreover, most research on college access focuses on students who attend 4-year or more elite institutions, rather than community colleges (Kirst and Bracco, 2004; Perna, 2006; Perna \& Thomas, 2008). Thus, more understanding is needed about the factors that are related to Hispanics' enrollment in community colleges and in HSIs.

Perna (2006) and Perna and Thomas (2008) developed a holistic model of college access that incorporates students' perceptions of their opportunity structures, as well as their access to resources. It recognizes four contextual levels of influence on college choice: individual, school, higher education context, and broader social, economic, and political context. The model draws on Bourdieu's (1986) concept of habitus, which stipulates that students develop a sense of possibilities for their educational advancement based on their family socialization and schooling experiences (McDonough, 1997). The model also recognizes that 
students draw on several types of resources, including human, financial, cultural, and social capital, when considering various postsecondary options (Bourdieu, 1986; Nuñez, McDonough, Ceja, \& Solorzano, 2008; Perna, 2006; Perna \& Thomas, 2008). Human capital includes academic skills, financial capital includes monetary resources, cultural capital includes information about higher education, and social capital includes the potential for social networks to facilitate access to skills or information about higher education (Bourdieu, 1986; McDonough, 1997; McDonough \& Nuñez, 2007). In this model, demographic background factors also play an important role in conditioning college destinations.

\section{METHODS}

Our central research question was: How are factors related to demographics, habitus, and various types of capital associated with enrollment patterns in community colleges, particularly those community colleges that are HSIs? We first explored the characteristics of community college students from different racial/ethnic groups, then compared characteristics of students in HSIs versus non-HSIs. Finally, we analyzed the predictors of enrollment in an HSI versus non-HSI, both for community college students as a whole, and separately for Hispanic students. For brevity's sake, we sometimes use the terms 2-year HSI to represent a community college that is an HSI and 2-year non-HSI to represent a community college that is not an HSI. 
The Beginning Postsecondary Students Longitudinal Study 2004 (BPS:

04), collected by the U.S. Department of Education National Center for Education Statistics, served as this study's data source. These data consist of information collected from a nationally representative sample of first-time, first-year beginning students, who were surveyed in their first year of college (the 2003-4 academic year). These students were surveyed about their demographic and financial backgrounds, high school academic experiences, college application process, and reasons for choosing colleges. BPS: 04 data were supplemented with information provided by the students' institutions about their financial aid status, and how students were paying for their education (National Center for Education Statistics, 2008a).

Using BPS: 04 data afforded us the opportunity to conduct our study using the most recent nationally representative data collected on the college enrollment patterns of first-time, first-year college students, which was a critical consideration, given Latinos' growth in the college-age population. Because the sample included students of diverse ages enrolled in diverse kinds of institutions, we were able to gain insight about the enrollment patterns of non-traditional older students, as well as traditional college-aged students, in different institution types. We were also able to draw a large sample of first-time, first-year beginning students enrolled in community colleges. Moreover, because BPS: 04 includes information about demographic factors, high school academic preparation, the 
college application process, and students' financial aid packages, this dataset allowed us to examine more theoretically driven analytic models that account for multiple factors related to college choice.

\section{Variables}

This study's dependent variable was whether the student enrolled in a 2year HSI or non-HSI. Two variables contained in BPS: 04 were used to create this dichotomous outcome: whether the first institution that the student enrolled in during the 2003-4 academic year was a community college and whether the student's first institution was a HSI or non-HSI.

Several independent variables were used in these analyses based on the conceptual framework presented above. Demographic characteristics included gender (male, female); student race/ethnicity ${ }^{\mathrm{ii}}$ (Latino, non-Latino White, nonLatino Black, Asian, and multiple/other races/ethnicities, including American Indian or Alaska Native, Native Hawaiian or Pacific Islander, or multiracial individuals); student's current age (19 or younger, 20-23 years of age, and 24 or older); and immigration status (first generation - student born outside the U.S., second generation - student born inside the U.S. and one or both parents born outside the U.S., and third generation - student and parents born in the U.S.).

Parental and student socioeconomic status was assessed with two variables: parent's highest level of education completed (high school diploma or less; some college, and a college degree or more) and student's income reported 
as income quartiles in the data source. In addition to being an indicator of socioeconomic status, parental education was also used to represent to access to cultural capital (Walpole, 2007). To address financial capital, the income quartiles were adjusted to account for whether or not the student was financially dependent or independent. For financially dependent students, adjusted incomes corresponded to the following income quartiles: low income (between $\$ 0$ and $\$ 30,999$ ); low-mid income (between $\$ 31,000$ and \$56,999); high-mid income (between $\$ 57,000$ and $\$ 88,999$ ); and high income (equal or greater than $\$ 89,000$ ). For financially independent students, adjusted incomes corresponded to the following income quartiles: low income (between $\$ 0$ and \$7,999); low-mid income (between $\$ 8,000$ and $\$ 19,999$ ); high-mid income (between $\$ 20,000$ and $\$ 37,999$ ); and high income (equal or greater than $\$ 38,000$ ). Urban or rural residential location during high school was also included.

Educational experiences and expectations were also included as independent variables in this analysis. Measures of the student's high school preparation (academic capital) included: the student's grade point average (GPA) (3.0 or better compared to 2.9 or below); the highest math course completed (algebra; algebra II/trigonometry; calculus); and whether the student received Advanced Placement credit (yes/no). Students were also asked the reasons for selecting their first institution. Possible reasons for selecting their first institution included: affordability or financial reasons; location; personal or family reasons; 
academic programs or coursework offered; and the institution's reputation. These indicators were included to explore the extent to which financial capital, social capital, academic capital, and cultural capital were related to students' enrollment in a community college that was or was not an HSI. Students were also asked whether or not they expected to earn a bachelor's degree or higher or if they had intentions to transfer institutions. Along with reasons for attending college, educational or transfer expectations might reflect a student's habitus, or how s/he was socialized to consider different postsecondary options or to develop a broader sense of educational possibilities.

Finally, a set of risk index and nontraditional student indicators that have been identified in previous research (Greene, Marti, \& McClenney, 2008; Horn \& Premo, 1995) were also assessed in BPS: 04. These indicators reflect timing, academic preparation, or financial or familial responsibilities that could place students at increased risk for not completing college. They include the following factors: delayed enrollment; not having earned a high school diploma; part-time enrollment; being financially independent; having dependents; single parent status; or full-time employment (Horn \& Premo, 1995). While not enough variability was present to include each of these risk index or nontraditional indicators separately, we created a risk index variable that noted if a student had $0,1,2,3$, or 4 to 7 risk factors present. 
First, we conducted chi-square tests to compare distributions in selected variables across groups, both for students from different racial/ethnic groups attending community college, and for students attending HSIs versus non-HSIs. Then we ran a logistic regression model to predict enrollment in an HSI versus non-HSI for the entire sample. Based on previous results from the chi-square tests for equal distributions that suggested that variables in the analysis were not equal across racial/ethnic groups, we then decided to test if variables from the logistic regression model operated differently for each of the racial/ethnic groups. Therefore, we conducted a Chow test (an F-ratio test) to determine whether the regression coefficients corresponding to different variables were similar for members of different racial/ethnic groups (Chow, 1960).

These test results suggested that, across the different racial/ethnic groups, the variables in the full logistic regression model were associated with HSI enrollment in different ways. One implication of such results is that it is worthwhile to present the disaggregated results for different racial/ethnic groups, as well as for the sample as a whole. Because of the Chow test results, we present the logistic regression results for Hispanics separately. While it is beyond the scope of this paper to compare results for all racial/ethnic groups, the remaining results are available from the authors. Each of these statistical tests was performed in SAS 9.2 using the survey procedures to account for the complex sample design of BPS: 04, so that our results could be as generalizable as possible to all first- 
time, first-year beginning students enrolled in community colleges during the 2003-4 academic year.

\section{Limitations}

Our study contributes to the understanding of Latino and other students' access to community colleges, particularly 2-year HSIs. However, as with any study, there are some limitations. The BPS: 04 sample was intended to be representative of all first-time, first-year beginning students, rather than institutions or institution types. So while we had access to students from a wide range of demographic backgrounds and institution types, the sample of community colleges and 2-year HSIs that students were drawn from may not have been representative of all community colleges and 2-year HSIs across the nation. Also, due to the limited variables in the dataset regarding students' high school backgrounds and experiences, we were limited in our capacity to ascertain relationships between the high school context and enrollment in different types of institutions. In addition, we were constrained in our ability to calculate the impact of specific risk factors since some of these were too correlated with other variables or their sample sizes were too small.

Moreover, while we considered urbanicity in determining HSI enrollment, we did not examine more closely the effect of being in a certain region, state, or other locality on this outcome. HSIs are located only in certain states and not in others and thus not accessible to some students who solely consider local higher 
education options. Moreover, state policies could affect pathways into community colleges; for example, limitations on affirmative action in some states may channel underrepresented students into community colleges as an alternative pathway toward 4-year postsecondary public education. Alternatively, the proportion of Hispanics in a given state might also affect their enrollment patterns in 2-year institutions (O'Connor, Hammack, \& Scott, 2010). Thus, our study may not have captured the full effects of geography on HSI enrollment.

\section{RESULTS}

Table 1 presents comparisons across the five racial/ethnic groups based on the chi-square tests for equal distributions for all students enrolled in community colleges.

\section{[INSERT TABLE 1]}

Statistically significant differences were noted for several of the variables among the five racial/ethnic groups. Among most racial/ethnic groups of community college students, particularly Latinos and Blacks (62\% and 64\%, respectively), female students outnumbered male students. Hispanic and Black community college students were also more likely to be of non-traditional age and to have risk factors for not completing college. Over two-thirds (68\%) of Asian and onethird $(33 \%)$ of Latino students were first-generation immigrants.

Hispanics were much more likely than other groups to be first-generation college-going students; over two-thirds (68\%) fit this category. About twice as 
many Latino, Black, and Asian as White community college students came from low-income families. Almost all Hispanic and Asian community college students (97\% and 98\%) came from urban areas. Black students tended to have lower high school GPAs than the other groups; however, Latinos appeared to have taken the lowest levels of math among all of the groups. Very few students in general had earned AP Credit in high school; Asians were most likely to have done this. There were significant differences among students from different groups with respect to all of their reported reasons for attending colleges, with the exception of considering reputation. Location was most important to all groups, particularly to Whites. Whites (66\%), followed by Asians (55\%) and Hispanics (54\%), were most likely to report that affordability was a consideration. Hispanic and Black students were slightly more likely than White and Asian students to report that academic programs and coursework, as well as personal and family reasons, affected where they attended community college. While groups were similar in their bachelor's degree expectations, Asian and White students were more likely than others to intend to transfer.

As Table 1 shows, almost four in ten Hispanic community college students (39\%), compared with about two in ten Asian (21\%), one in ten Black (10\%), and fewer than $10 \%$ of White students, attended 2-year HSIs. Table 2 indicates that few statistically significant differences were found among all variables when comparing students enrolled in a 2-year HSI compared to a 2-year non-HSI. 


\section{[INSERT TABLE 2]}

Students enrolled in HSIs were less likely to indicate that reputation was a reason for attending their college. They were more likely to have earned AP credit in high school and more likely to intend to transfer.

Table 3 presents the full logistic regression model results predicting enrollment among all community college students in a HSI or non-HSI.

\section{[INSERT TABLE 3]}

Male students had 26\% higher odds of enrolling in a 2-year HSI compared to a 2year non-HSI, holding all other variables in the model constant. Latino students, Asian students, and students from other or multiple race backgrounds had much higher odds than did White students of enrolling in a 2-year HSI. Urban residential location had a strong, positive association with a student attending a 2year HSI. Students with a high school GPA of 3.0 or better had increased odds of enrolling in a 2-year HSI, as did students who had earned AP credit in high school, expected to earn a bachelor's degree or higher, and intended to transfer to another institution. Holding other variables constant, students with one or more risk factors, compared to those who had none, had much higher odds of enrolling in a 2-year HSI.

Table 4 presents logistic regression model results predicting Latino students' enrollment a 2-year HSI versus 2-year non-HSI. In many ways, 
associations noted for the full community college sample presented in Table 3 did not operate in the same ways for the subsample of Latino students.

\section{[INSERT TABLE 4 HERE]}

Latino males, compared with Latina female students, had $43 \%$ higher odds of enrolling in a 2-year HSI versus a 2-year non-HSI. In contrast to findings for the larger sample, second generation Latino students, meaning students born in the U.S. with one or both parents born outside the U.S., had lower odds of enrolling in a 2-year HSI versus a 2-year non-HSI, compared to their third generation counterparts (that is, native-born Latinos with native-born parents). Latino students indicating that academic programs or coursework were the primary reasons for attending their institution had lower odds of enrolling in a 2-year HSI.

Again, a strong, positive association was noted between urban residential location and enrollment in a 2-year HSI among Latino students. Similar to patterns for the larger sample, Latino students with a high school GPA of 3.0 or better and high school AP credits had increased odds of enrolling in a 2-year HSI. Moreover, although bachelor's degree expectations became non-significant in predicting HSI enrollment among the Latino students, Latino students who intended to transfer institutions were over twice (2.20 times) as likely to enroll in a 2-year HSI versus a 2-year non-HSI. Similar to results for whole sample, an increased presence of risk factors and nontraditional student indicators were related to Latino students' enrollment in a HSI. However, a sharper gradient in 
this relationship was observed among Latinos - that is, as the number of risk factors increased among Latino students, so did the likelihood that Latino students would enroll in a 2-year HSI over a 2-year non-HSI.

\section{DISCUSSION}

This study offers insight into the factors that distinguish Hispanic community college students from others and those factors that distinguish students enrolled in 2-year HSIs from students enrolled in 2-year non-HSIs. Community colleges and HSIs that are community colleges both serve broad audiences and carry several missions. In light of this fact, along with the limited research about 2-year HSIs, we were not sure whether the predictors of students entering 2-year HSIs would be distinct from the predictors of those entering any other community college. However, our study reveals some interesting comparisons about different racial/ethnic groups in community colleges as well as the distinct institutional contexts (particularly the student compositions and peer environments) within which 2-year HSIs operate.

Our research confirms the critical role that 2-year HSIs play in offering Latino community college students access to higher education. Latinos comprise about half of the students in 2-year HSIs. In addition to being Latino, being Asian or from a multiracial background is positively related to 2-year HSI enrollment versus 2-year non-HSI enrollment compared to White students. This suggests that HSIs play an important role in providing access to non-White community college 
students. Part of this may be by virtue of the fact that HSIs are concentrated in urban areas, where Hispanic and Asian community college students are also overwhelmingly concentrated (Santiago, 2006). Moreover, although immigration status was not significant in predicting HSI enrollment across the whole sample, our study suggests that 2-year HSIs enroll first-generation immigrants (who are the majority of Asian American community college students) at higher rates than other community colleges.

Our research also suggests that, while females significantly outnumber males among Latino community college students by nearly 2 to 1 , being male is actually positively related to enrolling in a 2-year HSI versus 2-year non-HSI, among all community college students, as well as Latino students in particular. This finding is quite interesting, given the concern about low college enrollment and attainment rates of Latinos (Saenz \& Ponjuan, 2009). Our results suggest that 2-year HSIs are serving a subpopulation of Hispanic students that have elicited much policy concern and are taking on a special role in supporting Latino males to pursue and succeed in higher education. Whether or not targeting males is intentional on the part of HSIs, this is a new finding and one worthy of further exploration.

Given Hispanics' historically low college attainment rates, it is not surprising that Hispanic community college students are far more likely to be first-generation college-going students than members of other racial/ethnic 
groups. Moreever, being first-generation college-going is independently and positively associated with 2-year HSI enrollment, versus 2-year non-HSI enrollment, for Latino students. This may be related to the fact that many HSIs recruit or enroll high proportions of low-income students. However, income was not an independent predictor of whether or not Hispanics enrolled in a 2-year HSI. It is possible that those Hispanic students whose parents have not gone to college have less access to cultural capital regarding the college-going experience and thus rely more on other Hispanics in their social networks to gather information about postsecondary options (McDonough, 1997; Perez \& McDonough, 2008). Because Hispanics are already overrepresented in HSIs, they might be likely to direct one another to HSIs because of the familiarity of those institutions. In any case, 2-year HSIs, compared with their 2-year non-HSI counterparts, appear to be serving a subpopulation of Hispanic students with additional needs for cultural capital to navigate the postsecondary system.

First-generation students tend to complete college at lower rates than other students (Nuñez \& Cuccaro-Alamin, 1998). Likewise, students with other characteristics such as delayed timing of their academic careers, or competing familial or financial responsibilities, complete college at lower rates (Horn \& Premo, 1995). In addition to having much higher odds of being first-generation, Latino community college students are more likely than others to be older and to have other non-traditional characteristics that place them at risk for not 
completing college. Moreover, our research suggests that students with such risk factors have much higher odds (in many cases are twice as likely) to enroll in 2year HSIs versus non-HSIs, holding other factors (such as being Hispanic and of an older age at first enrollment) constant. In general, then, the portrait of 2-year HSIs that emerges is a sector, that compared with its non-HSI counterparts, is disproportionately serving Hispanic students who face additional challenges to competing postsecondary education and who do not fit the profile of a traditional college student on a wide range of dimensions - male, first-generation collegegoing, working, supporting a family, attending part-time, delaying higher education, and never having completed a diploma.

On the other hand, Hispanic community college students (as well as community college students in general) who attend 2-year HSIs appear to score higher on certain academic capital characteristics, holding other factors constant. Hispanic students who have earned higher GPAs in high school and AP credits are actually more likely to attend 2-year HSIs, compared with non-HSIs. These higher scores on academic preparation indicators perhaps do not appear consistent with the findings that Hispanic community college students also are more likely to have other demographic and risk factors that negatively predict college completion. However, these findings may also reflect the influence of the exogenous variable of state academic preparation levels. Specifically, among the four states with the highest number of HSIs, California, Texas, New York, and 
Florida, three consistently score among the top 10 states in high school students' AP test-taking and passing levels (College Board, 2010). These four states also have the highest number of high school students who have taken at least one AP exam (College Board, 2010).

Our analysis indicates that Latinos are more likely than other community college students in general to rank personal and family reasons and academic programs/coursework as important criteria in their reason for choosing a college. These findings support other literature highlighting that personal and family issues and accessibility of support programs can make community colleges particularly appealing postsecondary options for Hispanics (Gandara \& Contreras, 2009; Laden, 2001). Moreover, our results build on other small-scale qualitative studies (e.g., Perez \& McDonough, 2008; Santiago, 2007) to suggest that access to social capital, through social ties and family networks, can have a powerful influence on Latinos' college considerations. By placing comparatively more emphasis on family and personal issues in their considerations of postsecondary options, Latinos might be taking into account factors that are underexplored in traditional econometric models of college choice (Perna, 2006). They might evidence a habitus that places more value on social and cultural concerns. More research is needed to develop models of college choice that reflect Latinos' perspectives. 
Our study indicates that about half of all community college students expect to transfer and three-quarters expect to earn a bachelor's degree, with these proportions being somewhat higher among Asian Americans. Our findings also reveal that among all community college students, those who expect to earn a bachelor's degree and intend to transfer have higher odds of enrolling in a 2-year HSI, compared with a 2-year non-HSI, all other factors being held constant. For Latino community college students, expecting to earn a bachelor's degree is not a significant predictor of enrolling in a 2-year HSI, but intending to transfer is. Therefore, despite some demographic and background conditions that might make Latino and other students in 2-year HSIs less likely to finish their college educations, first-time and first-year beginning students enrolled in 2-year HSIs actually intend to go further in their educations than their counterparts in other community colleges.

\section{Implications for Policy and Practice}

Our study suggests that among the universe of American community colleges, which themselves already serve large numbers of nontraditional, ethnically diverse, immigrant, and multilingual students (Cohen \& Brawer, 2008); those categorized as HSIs are providing even higher levels of postsecondary access to students from these backgrounds. Despite the additional challenges to college completion that 2-year HSI students face, these students expect to go further in their educations than other students. The emphasis that these students 
place on transfer and earning a bachelor's degree suggests the important role that HSIs can play in facilitating transfer and educational attainment, particularly for Hispanics, who have the lowest educational attainment. While community colleges have multiple missions, emphasizing and connecting the developmental and transfer functions may be the best way for these institutions to meet these students' needs and expectations. It is important to note here that our findings regarding the association between higher transfer or educational expectations and 2-year HSI enrollment could also reflect the presence of stronger transfer and articulation policies in the states where Hispanics and HSIs are concentrated (O’Connor, Hammack, \& Scott, 2010), which could heighten students' desires to transfer or complete bachelor's degrees. Regardless of the origin of these students' intentions and expectations, 2-year HSIs have an important role to play in facilitating access to 4-year degrees.

It has been argued that community colleges "cool out," or lower, students" educational aspirations, a condition which eventually limits their college attainment (Clark, 1960). Given HSI community college students' backgrounds and aspirations, our study suggests that community college HSIs ought to identify and maintain strategies to "warm up," rather than "cool out" students" expectations and to support students in actualizing their expectations. In fact, Laden and her colleagues' research $(2001,2008)$ indicates that 2-year HSIs (compared with 2-year non-HSIs) incorporate particularly effective academic and 
social supports, as well as community recognition and responsiveness, that not only promote Hispanics' enrollment in these 2-year HSIs, but encourage higher transfer rates of Hispanics to 4-year institutions. It is important that academic and social supports such as counseling, academic enrichment, personal and cultural support, scholarship-based aid, family involvement, and mentoring be adapted and available to all students, including those from non-Hispanic as well as Hispanic backgrounds (Gandara \& Contreras, 2009; Santiago \& Andrade, 2010). Strengthening student services is challenging in the current public higher education budget climate, but critical to advancing student degree completion. Partnerships across the P-20 sector can also facilitate the preparation of Hispanics for higher education. First, partnerships between the K-12 and higher education sector can help Hispanic students access academic, financial, cultural, and social capital that is critical to making a successful transition to college (Nuñez \& Oliva, 2009). Such partnerships can also support students in finding the college that is the right "fit" for them. Partnerships to help smooth the transfer from community colleges to 4-year institutions can also help students in HSIs to fulfill their own ambitions of obtaining a bachelor's degree. Such initiatives must involve building partnerships between 2-year HSIs and 4-year institutions of varying selectivity (including those that are highly selective) in order to counterbalance a potential tendency to reproduce institutional stratification and segregation for Hispanic students within the 4-year sector (Laden, 2001). 


\section{Implications for future research}

Our study suggests several directions for future research. First, more needs to be understood about how 2-year HSIs, compared with other community colleges, are serving individuals who face barriers to completing higher education. The two-year HSI audience appears to have even higher numbers of nontraditional and male students than might be expected, when several critical factors are taken into account. Second, the role of geographical context, such as the influence of state policies, in college choice of 2-year HSIs must also be further explored. O'Connor et al. (2010) found that being from a rural area significantly disadvantaged a Hispanic student's access to 4-year higher education, many other factors being held constant. Given that HSIs are concentrated in urban areas, this raises the question of how the availability of certain kinds of institutions in certain regions affects Latinos' postsecondary options and trajectories, including those toward 2-year HSIs.

Third, our study raises questions about whether theories about college choice sufficiently speak to the influence of factors like geographical context, family, and personal matters, as well as academic and financial factors for Latino students. While research suggests that these factors are important (Gandara \& Contreras, 2009), more research is needed about how, exactly, they figure in to the processes of college choice. Fourth, as our study was cross-sectional, we could not address the influence of attending a 2-year HSI on college experiences 
and outcomes. Although the research of Laden and her colleagues $(2001,2008)$ suggests that the environment in 2-year HSIs is supportive to Hispanic students' success, more research in this area is needed. For example, Greene, Marti, \& McClenney's (2008) research suggests that Hispanic community college students are more engaged than White students in their studies, but still have lower educational outcomes; it would be instructive to see whether this is the case in 2year HSIs versus 2-year non-HSIs. Further exploration of faculty and staff attitudes and behaviors would also enhance our understanding of the climate for Hispanic students in 2-year HSIs (Hubbard \& Stage, 2009).

Finally, if community colleges that are HSIs are disproportionately serving students from groups that historically have had less college access and are attending college under particularly challenging conditions, it is essential for these institutions' personnel to identify, document, and share their institutions' successful practices, policies, and outcomes with a broader audience. This process can enhance research and practice about strategies that promote the postsecondary success of community college students from diverse backgrounds (Gasman, 2009). Two-year HSIs can make unique contributions in this regard. 


\section{REFERENCES}

Arbona, C., \& Nora, A. (2007). The Influence of Academic and Environmental Factors on Hispanic College Degree Attainment. The Review of Higher Education, 30(3), 247-270.

Baez, B., Gasman, M., \& Turner, C. S. V. (2008). On Minority-Serving Institutions. In M. Gasman, B. Baez, \& C. S. V. Turner (Eds.) Understanding Minority-Serving Institutions (pp. 3-17). Albany: SUNY Press.

Becker, G.S. (1993). Human Capital ( $3^{\text {rd }}$ ed.) Chicago: University of Chicago Press.

Bourdieu, P. (1986). The Forms of Capital. In J. G. Richardson (Ed.), Handbook of Theory and Research for the Sociology of Education (pp. 241-258). New York, NY: Greenwood.

Bowen, W., Chingos, M., \& McPherson, M. (2009). Crossing the Finish Line. Princeton: Princeton University Press.

Chow, G. C. 1960. "Tests of Equality Between Sets of Coefficients in Two Linear Regressions." Econometrica 28(3): 591-605.

Clark, B. (1960). The 'cooling out' function in higher education. American Journal of Sociology, 65(6), 569-576.

Cohen, A.M., \& Brawer, F. (2008). The American Community College (5 $5^{\text {th }}$ ed). San Francisco: Jossey-Bass. 
College Board. (2010). The $6^{\text {th }}$ annual AP report to the nation. New York: Author.

Contreras, F.E., Malcom, L.E., \& Bensimon, E.M. (2008). Hispanic-Serving Institutions: Closeted Identity and the Production of Equitable Outcomes for Latina/o Students. In M. Gasman, B. Baez, \& C. S. V. Turner (Eds). Understanding Minority-Serving Institutions (pp. 71-90). Albany: SUNY Press.

Dowd, A. (2008). Dynamic Interactions and Intersubjectivity: Challenges to Causal Modeling in Studies of College Student Debt. Review of Educational Research, 78(20), 232-259.

Gandara, P., \& Contreras, F. (2009). The Latino Education Crisis: The Consequences of Failed Social Policies. Cambridge, MA: Harvard University Press.

Gasman, M. (2009, October 11). Minority-Serving colleges deserve more respect. Chronicle of Higher Education. Retrieved December 10, 2009 from http://chronicle.com/article/Minority-Serving-Colleges-D/48726.

Greene, T. G., Marti, C. N., \& McClenney, K. (2008). The effort-outcome gap: differences for African American and Hispanic community college s tudents in student engagement and academic achievement. Journal of Higher Education, 79(5), 513-539.

Horn, L. \& Premo, M. (1995). Profile of Undergraduates in U.S. Postsecondary 
Education Institutions: 1992-1993. Washington, DC: National Center for Education Statistics.

Hubbard, S. M., \& Stage, F. K. (2009). Attitudes, perceptions, and preferences of faculty at Hispanic Serving and Predominantly Black Institutions. The Journal of Higher Education, 80(3), 270-289.

Johnson, J. N., Conrad, C. F., \& Perna, L.W. (2006). Minority-Serving Institutions of higher education: Building on and extending lines of inquiry for the advancement of the public good. In C. F. Conrad \& R. Serlin (Eds). The Sage handbook for research in education (pp. 263-277). Thousand Oaks: Sage.

Kelly, A. P., Schneider, M., \& Carey, K. (2010). Rising to the Challenge: Hispanic College Graduates as a National Priority. Washington, DC: American Enterprise Institute.

Kirst, M. W., \& Bracco, K. R. (2004). Bridging the great divide: How the K-12 and postsecondary split hurts students, and what can be done about it. In M. W. Kirst, \& A. Venezia (Eds.), From high school to college: Improving opportunities for success in postsecondary education (pp. 130). San Francisco, CA: Jossey-Bass.

Laden, B. V. (2001). Hispanic-Serving Institutions: Myths and realities. Peabody Journal of Education, 76(1), 73-92. 
Laden, B.V., Hagedorn, L.S., \& Perrakis, A. (2008). Donde estan los hombres?: Examining success of Latino male Students at Hispanic Serving community colleges. In M. Gasman, B. Baez, \& C.S.V. Turner (Eds.) Understanding Minority-Serving Institutions (pp. 127-140). Albany: State University of New York Press.

Martinez, M.C. (2002). Postsecondary participation and state policy: meeting the future demand. Sterling, VA: Stylus.

McDonough, P. (2007). Choosing Colleges. Albany, NY: State University of New York Press.

McDonough, P., \& Nuñez, A.-M. (2007). Bourdieu's Sociology of Education: Identifying Persistent Inequality, Unmasking Domination, and Fighting Social Reproduction. In C.A. Torres \& A. Teodoro (Eds.), Critique and Utopia: New Developments in the Sociology of Education (pp. 139-154). New York: Rowman \& Littlefield.

Mercer, C.J., \& Stedman, J.B. (2008). Minority-Serving Institutions: Selected Institutional and Student Characteristics. In M. Gasman, B. Baez, \& C. S. V. Turner (Eds.) Understanding Minority-Serving Institutions (pp. 28-42). Albany: SUNY Press.

Mullin, C. M., \& Phillippe, K. (2009). Community college enrollment surge. Washington, DC: American Association of Community Colleges. National Center for Education Statistics. (2008a). Beginning Postsecondary 


\section{Students Longitudinal Study (BPS: 04/06) Methodology Report.}

Washington, DC: National Center for Education Statistics.

National Center for Education Statistics. (2008b). The Condition of Education 2008. Washington, DC: Author.

National Center for Education Statistics. (2009). The Condition of Education 2009. Washington, DC: Author.

Nuñez, A.-M., \& Cuccaro-Alamin, S. (1998). First-generation students: Undergraduates whose parents never enrolled in postsecondary education. Washington, DC: National Center for Education Statistics. Nuñez, A.-M., McDonough, P., Ceja, M., \& Solorzano, D. (2008). Diversity Within: Latino college choice and ethnic comparisons. In C. Gallagher (Ed.) Racism in Post-race America: New Theories, New Directions (pp. 267-284). Chapel Hill: Social Forces Publishing.

Nuñez, A-M., \& Oliva, M. (2009). Organizational Collaboration to Promote College Access: a P-20 Framework. Journal of Hispanic Higher Education, 8(4), 322-339.

O'Connor, N., Hammack, F. M., \& Scott, M. A. (2010). Social capital, financial knowledge, and Hispanic student college choices. Research in Higher Education, 51(1), 195-219.

Pascarella, E.T. (2006). How College Affects Students: Ten Directions for Future Research. Journal of College Student Development, 47(5), 508-520. 
Perez, P. A., \& McDonough, P. M. (2008). Understanding Latina and Latino college choice: A social capital and chain migration analysis. Journal of Hispanic Higher Education, 7(3), 249-265.

Perna, L. W. (2006). Studying college access and choice: a proposed conceptual model. In J. Smart (Ed.), Higher Education: Handbook of Theory and Research (Vol. XXI, pp. 99-1 157). Cambridge, MA: Springer.

Perna, L. W., \& Thomas, S.L. (2008). Theoretical Perspectives on Student Success: Understanding the Contributions of the Disciplines. San Francisco: Jossey-Bass.

Pew Foundation. (2008). U.S. Population Projections: 2005-2050. Retrieved from http://pewhispanic.org/files/reports/85.pdf on February 18, 2008.

Saenz, V. B., \& Ponjuan, L. (2009). The vanishing Latino male in higher education. Journal of Hispanic Higher Education, 8(1), 54-89.

Santiago, D. A. (2006). Inventing Hispanic-Serving Institutions (HSIs): The basics. Washington, DC: Excelencia in Education.

Santiago, D. A. (2007). Voces (Voices): A Profile of Today's Latino College Students. Washington, DC: Excelencia in Education.

Santiago, D., \& Andrade, S. J. (2010). Emerging HSIs: Serving Latino Students. Washington, DC: Excelencia en Education.

Smith, D.G., \& Wolf-Wendel, L. (2005). The Challenge of Diversity: Involvement 
or Alienation in the Academy? Hoboken, NJ: Wiley.

St. John, E. P. (2003). Refinancing the College Dream: Access, Equal

Opportunity, and Justice for Taxpayers. Baltimore, MD: Johns Hopkins University Press.

Walpole, M.B. (2007). Economically and Educationally Challenged Students in Higher Education: Access to Outcomes. ASHE-Higher Education Report Series, 33(3), 1-113. 


\begin{tabular}{|c|c|c|c|c|c|}
\hline Variables & $\begin{array}{c}\text { Latino } \\
(\mathbf{n} \sim \mathbf{1 , 6 5 0})\end{array}$ & $\begin{array}{c}\text { Non- } \\
\text { Latino } \\
\text { White } \\
(\mathbf{n} \sim \mathbf{5 , 4 0 0 )}\end{array}$ & $\begin{array}{c}\text { Non- } \\
\text { Latino } \\
\text { Black } \\
(\mathbf{n} \sim \mathbf{1 , 6 0 0 )}\end{array}$ & $\begin{array}{c}\text { Asian } \\
(\mathbf{n} \sim 350)\end{array}$ & $\begin{array}{c}\text { Multiple/Other } \\
\text { Races/Ethnicities } \\
(\mathbf{n} \sim 550)\end{array}$ \\
\hline \multicolumn{6}{|l|}{ 2-year Institution $* * *$} \\
\hline HSI & 38.66 & 6.59 & 9.76 & 21.22 & 14.65 \\
\hline Non-HSI & 61.14 & 93.41 & 90.24 & 78.78 & 85.35 \\
\hline \multicolumn{6}{|l|}{ Gender $* * *$} \\
\hline Male & 38.16 & 43.28 & 36.48 & 52.19 & 41.53 \\
\hline Female & 61.84 & 56.72 & 63.52 & 47.81 & 58.47 \\
\hline \multicolumn{6}{|l|}{ Student's Current Age $* * *$} \\
\hline 19 or Younger & 49.90 & 53.77 & 39.82 & 61.34 & 52.16 \\
\hline $20-23$ & 19.92 & 14.75 & 24.87 & 16.56 & 21.49 \\
\hline 24 or Older & 30.18 & 31.48 & 35.31 & 22.10 & 26.35 \\
\hline \multicolumn{6}{|l|}{ Immigration Status $* * *$} \\
\hline First Generation & 33.33 & 5.45 & 14.51 & 67.89 & 20.00 \\
\hline Second Generation & 7.71 & 11.40 & 9.87 & 2.19 & 16.00 \\
\hline Third Generation & 58.96 & 83.15 & 75.62 & 29.92 & 64.00 \\
\hline \multicolumn{6}{|l|}{ Parent's Level of Education $* * *$} \\
\hline High School Diploma or Less & 68.34 & 47.33 & 55.62 & 47.43 & 46.31 \\
\hline Some College & 15.91 & 24.01 & 22.91 & 18.27 & 25.04 \\
\hline College Degree or More & 15.75 & 28.66 & 21.47 & 34.30 & 28.65 \\
\hline \multicolumn{6}{|l|}{ Income Quartiles $^{\mathbf{A}} * * *$} \\
\hline Low Income & 39.32 & 19.69 & 43.38 & 37.09 & 31.26 \\
\hline Low-mid Income & 27.30 & 25.99 & 29.56 & 25.85 & 29.97 \\
\hline High-mid Income & 19.69 & 28.05 & 18.77 & 14.66 & 21.95 \\
\hline High Income & 13.69 & 26.27 & 8.29 & 22.40 & 16.82 \\
\hline \multicolumn{6}{|l|}{ Residential Location $* * *$} \\
\hline Urban & 97.02 & 80.44 & 89.07 & 98.31 & 91.78 \\
\hline Rural & 2.98 & 19.56 & 10.93 & 1.69 & 8.22 \\
\hline \multicolumn{6}{|l|}{ High School GPA **** } \\
\hline 3.0 or Better & 31.42 & 33.62 & 23.25 & 33.47 & 35.95 \\
\hline 2.9 or Below & 68.58 & 66.62 & 76.75 & 66.53 & 64.05 \\
\hline \multicolumn{6}{|l|}{ Highest Math Course } \\
\hline \multicolumn{6}{|l|}{ Completed in High School } \\
\hline Algebra ** & 33.09 & 26.28 & 29.18 & 25.33 & 30.28 \\
\hline Algebra II/Trigonometry & 9.98 & 10.93 & 10.78 & 14.99 & 10.67 \\
\hline Calculus $* * *$ & 9.09 & 13.34 & 11.15 & 20.30 & 9.15 \\
\hline \multicolumn{6}{|l|}{$\begin{array}{l}\text { Earned Advanced Placement } \\
\text { Credit in High School } * *\end{array}$} \\
\hline Yes & 6.46 & 6.01 & 4.28 & 12.42 & 6.22 \\
\hline No & 93.54 & 93.99 & 95.72 & 87.58 & 93.78 \\
\hline
\end{tabular}

Reason Student Attended Community College 


\begin{tabular}{|c|c|c|c|c|c|}
\hline $\begin{array}{l}\text { Affordable/Financial Reasons } \\
* * *\end{array}$ & 54.37 & 65.60 & 47.92 & 54.95 & 54.43 \\
\hline Location $* * *$ & 74.38 & 82.64 & 74.36 & 75.21 & 79.81 \\
\hline Personal/Family Reasons * & 39.56 & 34.94 & 38.00 & 31.38 & 32.70 \\
\hline $\begin{array}{l}\text { Academic Programs/Coursework } \\
* * *\end{array}$ & 55.13 & 48.48 & 56.29 & 50.74 & 42.77 \\
\hline Reputation & 37.85 & 38.96 & 37.69 & 36.03 & 31.83 \\
\hline \multicolumn{6}{|l|}{ Student Expects to Earn BA or } \\
\hline \multicolumn{6}{|l|}{ Better } \\
\hline Yes & 75.24 & 73.19 & 76.58 & 82.36 & 78.52 \\
\hline No & 24.76 & 26.81 & 23.42 & 17.64 & 21.48 \\
\hline \multicolumn{6}{|l|}{ Student Intends to Transfer $* * *$} \\
\hline Yes & 50.95 & 54.14 & 49.42 & 69.99 & 57.45 \\
\hline No & 49.05 & 45.86 & 50.58 & 30.01 & 42.55 \\
\hline \multirow{3}{*}{\multicolumn{6}{|c|}{$\begin{array}{l}\text { Risk Factors and } \\
\text { Nontraditional Student } \\
\text { Indicators }{ }^{B}\end{array}$}} \\
\hline & & & & & \\
\hline & & & & & \\
\hline 0 Risk Factors Present $* * *$ & 21.61 & 28.63 & 18.68 & 25.29 & 22.96 \\
\hline 1 Risk Factor Present $* * *$ & 23.26 & 22.69 & 21.17 & 36.42 & 25.69 \\
\hline 2 Risk Factors Present & 15.38 & 13.45 & 14.30 & 17.54 & 17.09 \\
\hline 3 Risk Factors Present & 13.17 & 14.93 & 12.99 & 13.40 & 9.38 \\
\hline 4-7 Risk Factors Present $* * *$ & 26.58 & 20.30 & 32.86 & 7.35 & 24.88 \\
\hline
\end{tabular}

Weight: wta000; ${ }^{\mathrm{p}} \leq 0.05, * * \mathrm{p} \leq 0.01, * * * \mathrm{p} \leq 0.001$ for differences across racial/ethnic groups on the basis of $\chi^{2}$ tests for equal distributions.

${ }^{\text {A }}$ Income quartiles were provided in BPS:04 and were calculated from two variables contained in the data source, household income and dependent/independent student status. For dependent students, the quartiles correspond to the following household income groups: Low income: $\$ 0$ \$30,999; Low-mid income: \$31,000-\$56,999; High-mid income: \$57,000-\$88,999; and High income: incomes greater than $\$ 89,000$. For independent students, the quartiles correspond to the following household income groups: Low income: $\$ 0-\$ 7,999$; Low-mid income: $\$ 8,000-\$ 19,999$; High-mid income: $\$ 20,000-\$ 37,999$; and High income: incomes greater than $\$ 38,000$

${ }^{\mathbf{B}}$ Student risk factors include: delayed enrollment; no high school diploma; part-time enrollment; financially independent; has dependents; single parent; works full-time. The chi-square test was estimated for each risk factor category presented. Four to seven risk factors were pooled due to small sample sizes for anyone of the higher number of risk factors included individually in the analysis. 
Table 2. Weighted Percentages of Student Characteristics of First-Time, First-Year Beginning College Students Enrolled in Community Colleges by HSI/Non-HSI Status, Beginning Postsecondary Students Longitudinal Study 2004 (BPS: 04), n 9,550

\begin{tabular}{|c|c|c|}
\hline Variables & $\begin{array}{c}\text { HSI } \\
(\mathbf{n} \sim 900)\end{array}$ & $\begin{array}{l}\text { Non-HSI } \\
(\mathbf{n} \sim 8,650)\end{array}$ \\
\hline \multicolumn{3}{|l|}{ Gender } \\
\hline Male & 44.01 & 41.11 \\
\hline Female & 55.99 & 58.89 \\
\hline \multicolumn{3}{|l|}{ Student Race/Ethnicity *** } \\
\hline Non-Latino White & 26.65 & 61.75 \\
\hline Latino & 51.38 & 13.21 \\
\hline Non-Latino Black & 10.94 & 16.55 \\
\hline Asian & 5.82 & 3.53 \\
\hline Other/Multiple Races/Ethnicities & 5.21 & 4.96 \\
\hline \multicolumn{3}{|l|}{ Student's Current Age } \\
\hline 19 or Younger & 51.03 & 51.07 \\
\hline $20-23$ & 19.18 & 17.47 \\
\hline 24 or Older & 29.79 & 31.46 \\
\hline \multicolumn{3}{|l|}{ Immigration Status *** } \\
\hline First Generation & 28.13 & 13.07 \\
\hline Second Generation & 6.45 & 10.99 \\
\hline Third Generation & 65.42 & 75.94 \\
\hline \multicolumn{3}{|l|}{ Parent's Level of Education } \\
\hline High School Diploma or Less & 58.96 & 51.43 \\
\hline Some College & 19.12 & 22.66 \\
\hline College Degree or More & 21.92 & 25.91 \\
\hline \multicolumn{3}{|l|}{ Income Quartiles * A } \\
\hline Low Income & 34.33 & 27.34 \\
\hline Low-mid Income & 25.20 & 27.28 \\
\hline High-mid Income & 20.12 & 24.90 \\
\hline High Income & 20.45 & 20.48 \\
\hline \multicolumn{3}{|l|}{ Residential Location $* * *$} \\
\hline Urban & 99.60 & 83.93 \\
\hline Rural & 0.40 & 16.07 \\
\hline \multicolumn{3}{|l|}{ High School GPA } \\
\hline 3.0 or Better & 34.26 & 31.27 \\
\hline 2.9 or Below & 65.74 & 68.73 \\
\hline \multicolumn{3}{|l|}{ Highest Math Course Completed in HS } \\
\hline Algebra & 31.07 & 27.69 \\
\hline Algebra II/Trigonometry * & 8.40 & 11.27 \\
\hline Calculus & 12.43 & 12.24 \\
\hline \multicolumn{3}{|c|}{ Earned Advanced Placement Credit in HS ** } \\
\hline Yes & 8.61 & 5.66 \\
\hline No & 91.39 & 94.34 \\
\hline \multicolumn{3}{|c|}{ Reason Student Attended Community College } \\
\hline Affordable/Financial Reasons & 56.39 & 60.31 \\
\hline Location & 78.45 & 79.52 \\
\hline Personal/Family Reasons & 34.88 & 36.22 \\
\hline Academic Programs/Coursework & 46.89 & 51.38 \\
\hline Reputation $*$ & 33.91 & 38.76 \\
\hline \multicolumn{3}{|l|}{ Student Expects to Earn BA or Better } \\
\hline Yes & 83.96 & 73.21 \\
\hline No & 16.04 & 26.79 \\
\hline udent Intends to Transfer $* * *$ & $c_{-50}$ & \\
\hline
\end{tabular}


No

34.98

48.08

Risk Factors and Nontraditional Student Indicators ${ }^{B}$

0 Risk Factors Present $* * *$

18.37

26.49

1 Risk Factor Present *

22.59

2 Risk Factors Present

27.19

14.03

3 Risk Factors Present

15.85

13.79

4-7 Risk Factors Present

14.99

23.10

Weight: wta000; ${ }^{*} \mathrm{p} \leq 0.05, * * \mathrm{p} \leq 0.01, * * * \mathrm{p} \leq 0.001$ for differences among students enrolling in 2-year HSIs or 2-year non-HSIs on the basis of $\chi^{2}$ tests for equal distributions.

${ }^{A}$ Income quartiles were provided in BPS:04 and were calculated from two variables contained in the data source, household income and dependent/independent student status. For dependent students, the quartiles correspond to the following household income groups: Low income: \$0-\$30,999; Low-mid income: \$31,000$\$ 56,999$; High-mid income: $\$ 57,000-\$ 88,999$; and High income: incomes greater than $\$ 89,000$. For independent students, the quartiles correspond to the following household income groups: Low income: \$0\$7,999; Low-mid income: \$8,000-\$19,999; High-mid income: \$20,000-\$37,999; and High income: incomes greater than $\$ 38,000$

${ }^{\mathbf{B}}$ Student risk factors include: delayed enrollment; no high school diploma; part-time enrollment; financially independent; has dependents; single parent; works full-time. The chi-square test was estimated for each risk factor category presented. Four to seven risk factors were pooled due to small sample sizes for anyone of the higher number of risk factors included individually in the analysis. 


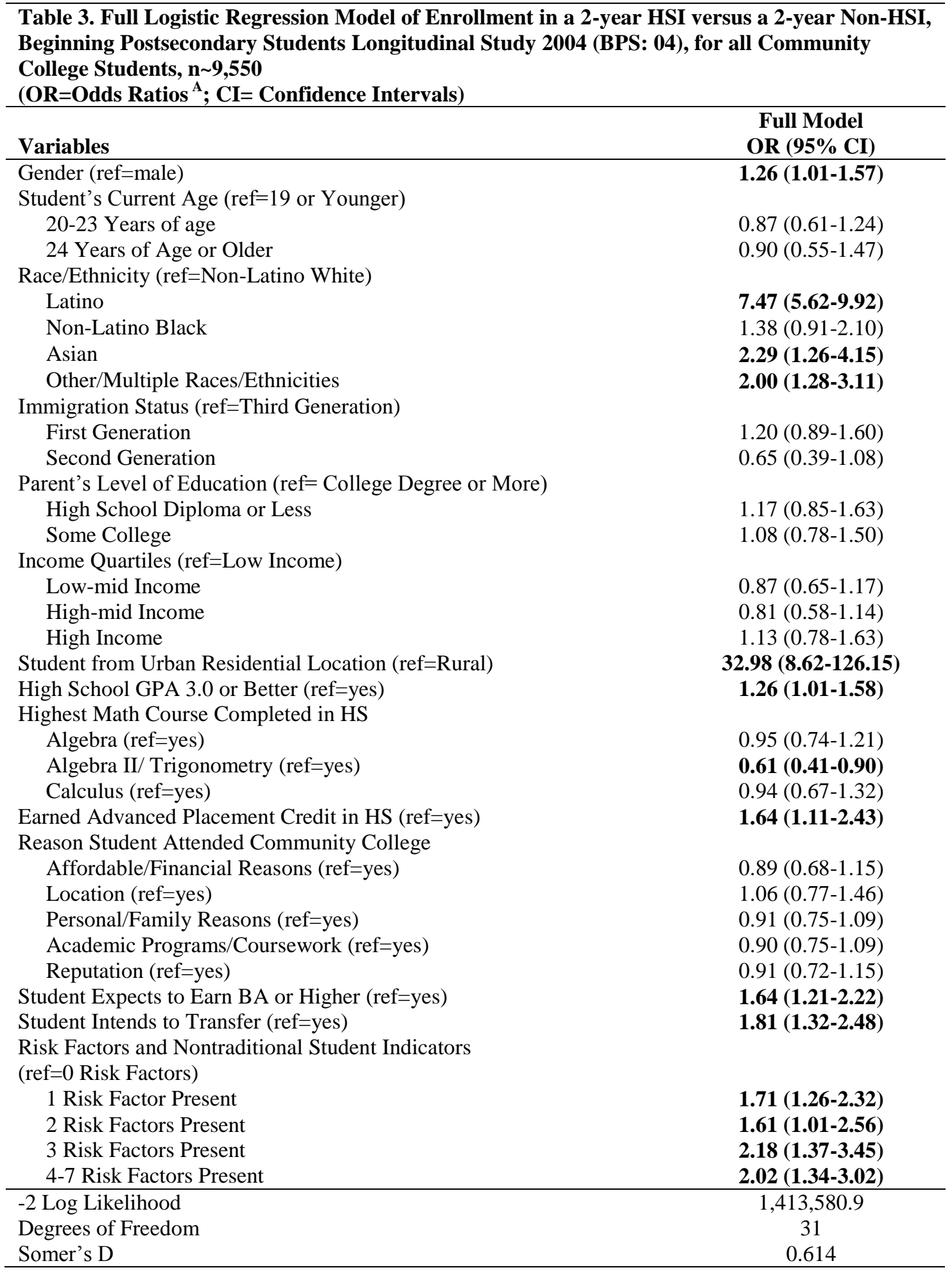

Weight: wta000; Bold values are statistically significant at least at the $\mathrm{p} \leq 0.05$ level.

${ }^{A}$ Odds ratios presented in this table demonstrate the odds of enrolling in a 2-year HSI, rather than a

2 -year non-HSI for each variable listed, holding all other factors constant in the model. 


\section{Table 4. Race-specific logistic Regression Model predicting Latino Community College Students' Enrollment in a 2-year HSI versus a 2-year Non-HSI, Beginning Postsecondary Students Longitudinal Study 2004 (BPS: 04), n 1,650 (OR=Odds Ratios ${ }^{\mathrm{A}}$; CI= Confidence Intervals)}

\begin{tabular}{|c|c|}
\hline Variables & $\begin{array}{c}\text { Latino Students } \\
\text { OR }(95 \% \text { CI })\end{array}$ \\
\hline Gender (ref=male) & $1.43(1.09-1.86)$ \\
\hline \multicolumn{2}{|l|}{ Student's Current Age (ref=19 or Younger) } \\
\hline 20-23 Years of age & $0.81(0.51-1.29)$ \\
\hline 24 Years of Age or Older & $0.91(0.48-1.73)$ \\
\hline \multicolumn{2}{|l|}{ Immigration Status (ref=Third Generation) } \\
\hline First Generation & $0.91(0.65-1.28)$ \\
\hline Second Generation & $0.50(0.31-0.81)$ \\
\hline \multicolumn{2}{|l|}{ Parent's Level of Education (ref $=$ College Degree or More) } \\
\hline High School Diploma or Less & $1.99(1.31-3.03)$ \\
\hline Some College & $1.17(0.74-1.85)$ \\
\hline \multicolumn{2}{|l|}{ Income Quartiles (ref=Low Income) } \\
\hline Low-mid Income & $0.75(0.53-1.05)$ \\
\hline High-mid Income & $0.84(0.53-1.05)$ \\
\hline High Income & $0.93(0.59-1.47)$ \\
\hline Urban Residential Location (ref=Rural) & $15.09(2.31-98.35)$ \\
\hline High School GPA 3.0 or Better (ref=yes) & $1.56(1.09-2.25)$ \\
\hline \multicolumn{2}{|l|}{ Highest Math Course Completed in HS } \\
\hline Algebra (ref=yes) & $1.03(0.69-1.54)$ \\
\hline Algebra II/ Trigonometry (ref=yes) & $0.76(0.47-1.23)$ \\
\hline Calculus (ref=yes) & $1.20(0.65-2.21)$ \\
\hline Earned Advanced Placement Credit in HS (ref=yes) & $1.86(1.01-3.45)$ \\
\hline \multicolumn{2}{|l|}{ Reason Student Attended Community College } \\
\hline Affordable/Financial Reasons (ref=yes) & $0.95(0.74-1.22)$ \\
\hline Location (ref=yes) & $1.24(0.89-1.72)$ \\
\hline Personal/Family Reasons (ref=yes) & $0.93(0.71-1.22)$ \\
\hline Academic Programs/Coursework (ref=yes) & $0.72(0.53-0.98)$ \\
\hline Reputation (ref=yes) & $0.99(0.71-1.36)$ \\
\hline Student Expects to Earn BA or Higher (ref=yes) & $1.42(0.96-2.12)$ \\
\hline Student Intends to Transfer (ref=yes) & $2.20(1.57-3.09)$ \\
\hline \multicolumn{2}{|l|}{ Risk Factors and Nontraditional Student Indicators ( $\mathrm{ref}=0$} \\
\hline \multicolumn{2}{|l|}{ Risk Factors) } \\
\hline 1 Risk Factor Present & $1.77(1.15-2.70)$ \\
\hline 2 Risk Factors Present & $1.96(1.19-3.24)$ \\
\hline 3 Risk Factors Present & $2.52(1.13-5.58)$ \\
\hline 4-7 Risk Factors Present & $3.27(1.56-6.84)$ \\
\hline -2 Log Likelihood & $484,080.26$ \\
\hline Degrees of Freedom & 27 \\
\hline Somer's D & 0.373 \\
\hline
\end{tabular}

Weight: wta000; Bold values are statistically significant at least at the $\mathrm{p} \leq 0.05$ level.

${ }^{A}$ Odds ratios presented in this table demonstrate the odds of enrolling in a 2-year HSI, rather than a 2year non-HSI, for each variable listed for that particular racial/ethnic group, holding all other factors constant in the model. 


\section{ENDNOTES}

${ }^{\mathrm{i}}$ This article uses the terms Latino and Hispanic interchangeably.

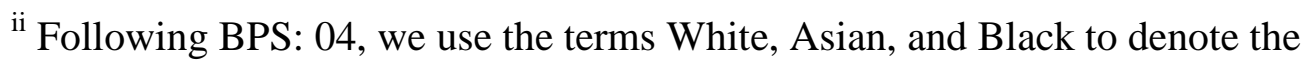
three largest racial/ethnic groups besides Hispanics. As we have noted, these groups do not include individuals of Latino background.

\section{ACKNOWLEDGMENTS}

The authors are grateful for the financial support of the UTSA College of Education and Human Development and the American Association of Hispanics in Higher Education in conducting this research. 